This process not only contributes to the emergence of global administrative law, but also creates a broad, universal recognition of the principles and concepts that global administrative law requires. It is concluded that the implementation of international norms, standards, procedures that operate on a global scale will help Ukraine to gradually build a European, sovereign, independent, democratic, social, legal state, whose main responsibility is to promote and protect human rights and freedoms, where a individual, his or her life and health, honor and dignity, integrity and security will be recognized as the highest social value as an effective mechanism of human-centered concept.

Key words: Globalization, Europeanization, Global Administrative Law, Public Administration, International Standards, Rule of Law, Human Rights.

DOI: 10.36695/2219-5521.4.2019.22

УДК 323.2

\title{
М.Б. СЕЛІНА
}

Марія Броніславівна Селіна, кандидат юридичних наук, заступник завідувача кафедри Національної академії Служби безпеки України*

ORCID: 0000-0002-2454-0605

\section{СПЕЦІАЛЬНА ІНФОРМАЦІЙНА ОПЕРАЦІЯ: ІСТОРІЯ СТАНОВЛЕННЯ}

Постановка проблеми. Глобалізація та стрімкий розвиток інформаційно-комунікативних технологій привнесли значні зміни на сталі погляди ведення військово-політичного протиборства. Зростання ролі інформаційних технологій та засобів масової інформації (далі - ЗМІ) призвели до поступового переходу конфліктів 3 суто збройного протиборства в інформаційний простір, який став новим «полем» протистояння. Інформаційні технології стали використовуватися в якості ключового засобу досягнення військово-політичних цілей різних держав, а інформація стала зброєю, яка не наносить фізичної шкоди безпосередньо, проте може стати «детонатором» для початку значних деструктивних процесів у суспільстві, у тому числі відправною точкою початку збройного протистояння. Зважаючи на це, більшість розвинених країн світу стали використовувати можливості спеціальних інформаційних операцій (далі - CIO) у власних цілях, у т.ч. з метою отримання переваги над супротивником без застосування зброї. На користь цього свідчать чисельні сучасні локальні конфлікти, перебіг яких ілюструє, що за допомогою використання сучасних інформаційно-комунікативних технологій можна якісно змінити характер бойових дій, а перемогу отримує та сторона, яка має інформаційну перевагу. Варто також зауважити, що за допомогою проведених СІО було спровоковано більшість сучасних конфліктів та кризових ситуацій. Проте все ж таки негативні або позитивні аспекти СІО залежать від суб'єкта їх проведення та мети, задля досягнення якої їх проводять. На жаль, у нашій країні розуміння СІО часто має негативне забарвлення. Головним чином, це пов'язано з тим, що їх потужні можливості широко використовуються Російською Федерацією для дестабілізації ситуації в Україні, маніпулювання суспільною думкою світової спільноти у вигідному для російського керівництва напрямку, а також і для впливу на розвиток суспільно-політичної ситуації всередині самої РФ.

Отже, сьогодні можна впевнено стверджувати, що СІО стали потужною зброєю сучасності, яка дає змогу суб'єкту їх проведення підготувати фундамент для забезпечення власних політичних, військових, економічних та інших інтересів, як на власній території, так і в інших країнах.

У зв'язку з цим необхідно констатувати, що вивчення та розуміння феномена СІО в усіх його аспектах, у т.ч. вміння якісно протидіяти проведенню деструктивних СIO з боку супротивників, у сучасний період $\epsilon$ однією з головних передумов забезпечення національних інтересів країни. Тому, враховуючи багатогранність цього явища, різноманітність форм та методів його здійснення, вбачається необхідним дослідження виникнення та становлення цього феномена, вивчення історичних фактів використання елементів СІО у військово-політичних протистояннях, проведення аналізу динаміки їх реалізації та наслідків проведення.

Аналіз останніх досліджень і публікацій. Дослідженням історичних аспектів зародження та розвитку СІО, вивченням їх ролі у збройних конфліктах в різні часи та епохи, займалися науковці та практичні працівники різних країн світу.

В Україні вивченням цього явища та історії його виникнення займались провідні вітчизняні вчені та науковці: В. Говоруха, В. Домарєв, О. Литвиненко, В. Остроухов, В. Петрик, Г. Перепелиця, Г. Почепцов, О. Старіш, Є. Скулиш, В. Толубко та інші. У Росії відповідному напряму досліджень присвячено роботи В. Лисичкіна, І. Панаріна, В. Прилуцького, С. Расторгуєва, Л. Шелепіна та інших, а в далекому зарубіжжі П. Дракера, Д. Рісмана, Т. Рона, Д. Тапскотта, Е. Тоффлера, Х. Шрадера та інших авторів.

Разом із тим у вітчизняній науковій літературі питання застосування методів та форм СІО у військовополітичних конфліктах, як у сучасному часі, так і у різні періоди історії, висвітлені досить фрагментарно.

(C) М.Б. Селіна, 2019

* Maria Selina, Ph.D. in Law, Deputy head of Department of the National Academy of Security Service of Ukraine 
Загалом така література містить загальні історичні відомості про використання окремих елементів СІО. Зважаючи на зазначене, проведення дослідження становлення та розвитку CIO, аналіз історичних фактів використання елементів СIО та вивчення динаміки їх застосування і наслідків проведення вважаємо необхідним й своєчасним.

Формулювання мети статті. Виходячи 3 цих міркувань метою статті є висвітлення становлення та розвитку CIO, дослідження і аналіз взаємозв’язку між науково-технічним прогресом та трансформацією іiі форм та методів проведення у різні періоди історії людства, вивчення впливу СІО на хід військово-політичного протиборства.

Виклад основного матеріалу. Як явище спеціальні інформаційні операції не є винаходом сьогодення. Такі методи інформаційно-психологічного впливу (далі - ІПВ), як дезінформація, пропаганда, залякування, які сьогодні використовуються для проведення СІО, мають дуже давню історію. Їх зародження почалось у глибокий давнині одночасно з виникненням збройного протистояння, як складова частина збройної боротьби у вигляді психологічного засобу ослаблення бойового духу супротивника та підняття бойового духу власних сил. 3 розвитком та удосконаленням інформаційних технологій розвивались та удосконалювалися i методи ІПВ. Так, відповідно до виду носіїв інформації та способу їі розповсюдження можна виділити чотири етапи розвитку цих методів: вербальний, паперовий, технічний та телекомунікаційний.

На першому етапі у якості основного носія та розповсюджувача інформації виступала людина. Способи передачі інформації обмежувалися вербальними технологіями, а саме: виступами ораторів, релігійних діячів, розповсюдженням чуток, а також використанням наочних засобів залякування.

На цьому етапі почалося залякування противника власною бойовою міццю (іноді уявною), застосування дезінформації, використання пропагандистських написів на каменях, деревах та будівлях. Відомості про перші спроби здійснення інформаційних операцій, зокрема використання методів ІПВ, містяться у стародавніх літописах, релігійній, філософській літературі та ін. Так, у Біблії розповідається історія Гедеона, який так залякав супротивника, що той розгубився і вдарив по своїх військах ${ }^{1}$.

Одними із найдавніших джерел, в яких згадується про застосування прийомів інформаційного протиборства, можна вважати «Стратагеми», - систематизовані у Стародавньому Китаї стратегії, що застосовувалися в політиці та військовій діяльності, які були схемами опосередкованого способу впливу, неявного маніпулювання чужою поведінкою, а також «Трактат про військове мистецтво» китайського полководця Суньцзи, який можна назвати однією 3 перших робіт 3 проведення інформаційних операцій². Сунь-цзи першим аргументував необхідність інформаційного впливу на супротивника. Він наголошував, що вінець мистецтва - підкорити супротивника без бою. У трактаті підкреслюється необхідність отримання інформації про супротивника, психологічної обробки власних населення і війська з метою досягнення єдності в суспільстві, здійснення інформаційних диверсій для розладнання військових союзів ворожої держави з іншими державами тощо ${ }^{3}$, важливе місце відводиться використанню т. зв. «шпигунів смерті» для дезінформації противника.

Дезінформація та пропаганда широко застосовувалися і в Стародавній Греції та Римі. Зокрема, потужним пропагандистським засобом став твір Юлія Цезаря «Записки про Галльську війну». Приклади й поради щодо здійснення психологічного впливу на окремих осіб та війська противника за воєнних та мирних умов містяться у працях відомого візантійського історика Прокопія Кесарійського. Відомості про окремі факти IПВ, спрямованого на розпалювання суперечностей у таборі супротивника, містяться у працях грецького історика Геродота. Загалом у творах античних авторів, зокрема Софокла, Фемістокла, Демосфена, Ісократа, Плутарха тощо чимало уваги приділено створенню методів впливу на свідомість людини 4 . До речі, класичним прикладом дезінформації є «троянський кінь», який зіграв вирішальну роль у троянській війні, а вираз «троянський кінь» наразі у колі професійних розвідників використовується для позначення операцій із дезінформації противника 3 подальшою його поразкою.

Методи ІПВ продовжують розвиватися та удосконалюватися в епоху Середньовіччя. Значний внесок у розвиток інформаційних операцій зробили араби часів Халіфату і монголо-татари, які розвинули деякі форми впливу на моральний стан своїх ворогів. Зокрема, останні широко застосовували дезінформацію противника та пропаганду. Пропаганда, що породжувала песимістичні настрої в таборі противника, була доведена монголами до великої досконалості. Так, під час походу в Південний Китай (1234-1271 рр.) монголам, які зіштовхнулися з величезною армією держави Сун, удалося деморалізувати ії шляхом поширення чуток про зраду уряду, i, щоб підтвердити чутки фактами, монголи через свою агентуру дійсно підкупили одного високопоставленого чиновника й самі ж допомогли викрити його 5 . Цей випадок негативного інформаційного впливу монголо-татар на війська противника і підриву морального стану населення за допомогою прийомів пропаганди можна назвати одним із методів, що використовується для проведення спеціальних інформаційних операцій.

Із збільшенням грамотності населення почався «паперовий» етап, який характеризувався розповсюдженням листування, початком друкування книг, газет та ін. У цей же період 3'явився ефективний засіб для розповсюдження пропагандистських матеріалів чи дезінформації - листівка.

Значних результатів з удосконалення засобів впливу на ворога досягли в Ордені єзуїтів у першій половині XVI століття. Крім здійснення систематизованого морального тиску на своїх противників, представники цього ордену вперше започаткували використання листівок, лозунгів та організували фахову підготовку його членів, яким доручалася справа дискредитації противника у воєнні та мирні часи.

Методи ІПВ продовжують широко використовуватися і у війнах Середньовіччя, для чого почалось застосування друкованих ілюстрованих «інформаційних» листівок. У цей же період Н. Макіавелі у творі 
«Государь» значну увагу приділяє проблемам інформаційного впливу на підданих та противників, ретельно розглядає питання доцільності акцій залякування та демонстрації правителем різних чеснот як необхідного боку політичної діяльності'.

Попри поступовий розвиток та поширення інформаційного впливу тогочасний рівень розвитку суспільства і науки не давав можливості значного зростання їх ролі в суспільному житті.

Поворотним моментом у історії інформаційних операцій став винахід друкарського станка та удосконалення видавничої справи. Книгодрукування і поява публічного друкованого інформаційного видання - газети - створили необмежені можливості для використання методів ІПВ у різних сферах суспільного життя. На даному етапі одна із ключових ролей у розвитку інформаційних операцій у військових умовах належить Наполеону Бонапарту, бойовим операціям якого передувало розповсюдження чуток про значну чисельну перевагу його військ, після чого розповсюджувалися памфлети та листівки. Для цього в армії Наполеона використовувалася польова типографія 3 комплектом іноземних шрифтів 7 . При Наполеоні в поліцейській системі створено відділи преси, театру і газет, до яких запрошувалися кращі журналісти країни. Їх використовували для пропаганди, дискредитації опозиції в країні та за їі межами.

Пропаганду та дезінформацію противника успішно використовувало багато монархів та полководців того часу. Про використання інформації для досягнення поставленої мети під час війни свідчать твори та діяльність Клаузевіца, Жофа, Суворова, Кутузова, Мілютіна, Міхневича та інших ${ }^{8}$.

Так, широким використанням специфічних тактичних прийомів, що мали національний характер та вживались як елемент військово-психологічного супроводу бойових дій, характеризувався один із найвидатніших періодів нашої історії, Козацька доба, під час якого відбувся розквіт розвідувальної та контррозвідувальної діяльності. Український дослідник Т. Чухліб наголошує, що на території Центральної та Східної Європи гетьман Богдан Хмельницький започаткував проведення прототипів СIO, використовував їх у багатьох битвах, особливо на початку Визвольної війни у 1648 році. Зокрема, шляхом поширення дезінформації він намагався посіяти паніку та невпевненість у власних силах серед ворожого війська. Узимку 1651 р. була проведена одна з найбільш грандіозних у ті часи в Європі розвідувально-психологічна операція. До Корони Польської були направлені близько двох тисяч українських шпигунів, які, зокрема, поширювали чутки про величезну бойову могутність армії Богдана Хмельницького, тим самим викликаючи панічні настрої серед місцевого населення9.

Проте неправильно стверджувати, що до цього козаки не використовували методи психологічного впливу. Так, Северин Наливайко, Петро Конашевич-Сагайдачний, Михайло Дорошенко, Іван Сулима, Дмитро Байда-Вишневецький та ін. започаткували традиції козацького військового мистецтва, т.зв. «військові хитрощі», елементи військово-психологічного супроводження бойових дій. За часів козацтва сягнули високого рівня розвиток та організація польової сторожово-розвідувальної служби, зовнішньої розвідки, контррозвідувальних заходів. При цьому завдяки всенародній підтримці стала особливо ефективною діяльність козацької розвідки, що, у свою чергу, стало можливим у результаті вміло проведеної пропаганди та формуванню позитивної думки про запорозьке військо серед місцевого населення. Дезінформація ворога вже у ті часи була одним із важливих методів зовнішньої розвідки козаків, за допомогою якого козаки поширювали панічні настрої у супротивника, організовували повстання, а також здобували розвідінформацію ${ }^{10}$. Дезінформація проводилася головним чином двома шляхами: через агентів, які вдавали з себе перебіжчиків 3 козацького табору, та через мужніх патріотів, які потрапляли до ворога i, приймаючи мученицьку смерть на тортурах, повідомляли ворогу «необхідну» інформацію. Зокрема, це спостерігалось під час боїв під Корсунем, Старокостянтиновом, Пилявцями, у ході Берестечкової кампанії тощо ${ }^{11}$.

3 середини ХІХ ст. винахід нових носіїв інформації - фотографії та наступне відкриття електрики й нових засобів розповсюдження інформації - телеграфу, телефону, радіо, кіно, а пізніше - телебачення дав поштовх початку третього «технічного» етапу розвитку та удосконаленню методів ІПВ. На цьому етапі значно посилилася наочність та образність засобів інформаційного впливу, збільшились можливості накопичення та зберігання інформації будь-якого об'єму. Стало можливим здійснення масового інформаційного впливу на населення різних країн світу. Можна стверджувати, що саме цей етап став переламним у розвитку та удосконаленні методів ІПВ. На цьому етапі відбувся перехід із суто військового їх використання у політичну площину. Поворотним пунктом у розвитку інформаційних операцій стала Перша світова війна, під час якої сторони намагалися вплинути на перебіг конфлікту за допомогою інформації та медіа. При штабах армій створювалися відповідні відділи й підрозділи, які організовували «війну слів» - агітацію супротивника. Пропаганда серед війська і населення противника з випадкової зброї перетворилася на один із провідних військових інструментів. Слід зауважити, що у 1874 р. на Брюссельській конференції з регламентації звичаїв війни вперше засуджено використання дезінформації. Декларацію цієї конференції було підтверджено на наступних Гаазьких конференціях у 1899-1907 роках. У підсумку жодна держава не перестала використовувати метод дезінформації як особливий військовий арсенал, а в офіційних військових документах, у т.ч. уставах, які були видані вже після Першої світової війни, дезінформацію «закамуфлювали» термінами «активне і пасивне тактичне та оперативне маскування» ${ }^{12}$.

Розвиток науки та техніки у XX ст. дав змогу значно удосконалити технологічну основу для проведення інформаційних операцій, що зробило їх одним із найефективніших засобів досягнення зовнішньо та внутрішньополітичних цілей. Вже у 20-х рр. минулого століття США поширювали радіопередачі на регіони своїх «традиційних інтересів» країни Латинської Америки. Великобританія - на свої колонії. Німеччина, яка домагалася 
перегляду умов Версальського миру - на німців Померанії і Верхньої Сілезії у Польщі, Судетів у Чехії. Тоді ж, у 30-х рр., інформаційні операції перестають бути додатком до збройних конфліктів і перетворюються на самостійне явище - як-от: німецько-австрійська радіовійна 1933-34 рр. з приводу приєднання Австрії до рейху13.

На початку 1939 р. міністерством пропаганди і штабом верховного командування Вермахту підписана угода «Про ведення пропаганди в період війни», де пропаганда розглядалась у якості найважливішого засобу ведення війни, який за своєю роллю прирівнювався до одного з родів військ.

Під час Другої світової війни супротивники активно застосовували такі самі методи інформаційних операцій, що й під час Першої світової війни. Гітлер надавав надзвичайно великого значення пропаганді. При цьому характерною рисою фашистської пропагандистської діяльності було грунтовне використання наукових розробок у цій сфері. Зокрема, настільними книгами рейхсміністра пропаганди Гебельса були праці Е. Бернейса. Необхідно також звернути увагу на високу ефективність пропагандистської діяльності у військовий період спеціалістів з Англії та США.

3 кінця 40-х до середини 80-х рр. минулого століття у світі відбулося чимало військових конфліктів - у Кореї, В’єтнамі, Афганістані, військові операції проти Іраку тощо, в яких також активно застосовувалися методі СІО. Але матеріально-технічна оснащеність, а, відповідно, й руйнівний потенціал таких операцій був незрівнянно вищій, ніж у роки Другої світової війни. Це зумовлено подальшим технічним прогресом та зростаючою роллю і місцем інформації у житті суспільства. Провідні країни світу використовували досвід, набутий під час проведення інформаційних операцій у Другій світовій війні. У 1949 р. в США була прийнята настанова FM-33-5 «Ведення операцій психологічної війни». У цьому документі зазначалось, що найважливішим засобом проведення інформаційно-психологічних операцій $є$ пропаганда як система заходів із поширення політичної інформації, а також наводилася ії класифікація за джерелом - «біла», «сіра», «чорна»; а також за змістом - політична й воєнна 14 . А вже у 1979 р. з'явився статут, який визначив концепцію, принципи організації та ведення інформаційно-психологічних операцій у збройних силах США - FM-33-1 «Психологічні операції» 15 . На початку 80-х рр. минулого століття роль інформаційно-психологічного впливу, інформаційних операцій у системі забезпечення національної безпеки США різко зросла і продовжувала удосконалюватися 3 урахуванням нових технічних та комунікативних можливостей. Так, яскравим та дієвим прикладом успішного проведення інформаційної операції з використанням можливостей ЗМІ та їх впливу на кінцевий результат була війна проти Іраку, що отримала назву «Буря в пустелі», де нові інформаційні технології вперше були застосовані у військових цілях. Окремі дослідники цієї війни зазначали, що війна в зоні Перської затоки може бути визначена як перша повномасштабна війна нового етапу в функціонуванні військових сил в умовах створення глобального інформаційного простору. «Буря в пустелі» стала першою в історії війною в прямій телетрансляції. Американські військові, використовуючи «м'яку цензуру», фактично вилучили з інформаційного поля повідомлення, в яких виправдовувалась протилежна сторона. Інформаційна операція ЗС США в Перській затоці проводилася за двома основними напрямами. Перший стосувався зовнішньополітичної сфери, метою якого було забезпечення підтримки контрзаходів проти Іраку, а також зміцнення позицій антиіракської коаліції. Другий напрям торкався безпосередньо військової сфери і спрямовувався на погіршення морально-психологічного стану населення та особового стану ЗС Іраку, що впливало на їх боєздатність ${ }^{16}$.

Наприкінці XX ст. полем для проведення СІО стають не лише традиційні мас-медіа, а Інтернет та соціальні мережі, що пов'язано зі значним розвитком цифрових і комп'ютерних технологій, їх глобалізацією. Так, під час конфлікту в Югославії вперше для проведення СIO була використана мережа Інтернет. Зокрема, мережею поширювалась інформація щодо «звірств» сербських солдат, приводились різні факти і погляди політиків та експертів тощо. Результатом вдало проведених західними спеціалістами СІО стала фактична капітуляція сербських збройних сил.

Сьогодні мережа Інтернет активно використовується Російською Федерацією для проведення СІО проти України, для чого російська сторона створює підконтрольні соціальні мережі, Інтернет-ЗМІ тощо. Зокрема, «кампанії» Російської Федерації із введення збройних сил та подальшої окупації АР Крим, «підтримки ополченців» так званих ДНР/ЛНР супроводжувалися діями, які мали всі ознаки підготовлених та продуманих за цілями, заходами та наслідками СIO, скерованих, з одного боку, на російську аудиторію, а, 3 іншого боку, на українську та західну аудиторію. Аналіз подій в АР Крим та на сході України свідчить, що Російською Федерацією реалізується проти України сценарій гібридної війни, де ключову роль, поряд із застосуванням сил спеціальних операцій, відведено саме СІО.

Отже, останні події, зокрема в Перській затоці в січні 1991 р., Югославії у 1999 р., i, звісно, гібридна війна на території нашої країни окреслили нові риси в уявлення про засоби та методи військово-політичного протиборства у сучасному інформаційному суспільстві.

Висновки. Спеціальні інформаційні операції не є здобутком сьогодення. Про використання перших форм ІПВ свідчать численні історичні, філософські та інші джерела. Їх зміна та удосконалення корелювалися з розвитком науки і техніки та розвитком способів обробки, фіксації і передачі інформації.

Проте, незважаючи на те, що практика застосування форм IПВ має тривалу історію, в якості одного 3 основних засобів військово-політичного протистояння вони постають саме у ХХ сторіччі. Глобалізація, значний розвиток інформаційно-комунікативних технологій, збільшення ролі ЗМІ тощо зробили СІО одним iз найбільш ефективних засобів досягнення зовнішньо та внутрішньополітичних цілей як у військовий, так і у мирний час, а коло їх використання поширилося на економічну, політичну та інші сфери життєдіяльності суспільства. 
1 Библия. Москва, 2002. 1376 с. С. 238.

2 Информационно-психологическая безопасность в епоху глобализации: учеб. пособ. / В.М. Петрик, В.В. Остроухов, А.А. Штоквиш и др. Киев, 2008. 543 с. С. 8-10.

3 Сучасні технології та засоби маніпулювання свідомістю, ведення інформаційних війн і спеціальних інформаційних операцій: навч. посіб. / В.М. Петрик, В.В. Остроухов, О.А. Штоквиш та ін. Київ, 2006. С. 8-9.

${ }^{4}$ Информационно-психологическая безопасность в епоху глобализации: учеб. пособ. / В.М. Петрик, В.В. Остроухов, А.А. Штоквиш и др. Киев, 2008. 543 с. С. 191-192.

5 Історія інформаційно-психологічного протиборства : підручник / Я.М. Жарков, Л.Ф. Компанцева, В.В. Остроухов, В.М. Петрик, М.М. Присяжнюк, Є.Д. Скулиш; за заг. ред. д.ю.н., проф., засл. юриста України Є.Д. Скулиша. Київ: Наук.-вид. відділ НА СБ України, 2012. 209 с. С. 50-51.

6 Макиавели Н. Государь. Москва: Планета, 1990. 79 с.

7 Інформаційна безпека держави: підручник / В.М. Петрик, М.М. Присяжнюк, Д.С. Мельник та ін. Київ: ДНУ «Книжкова палата України», 2016. 264 с. С. 118-122.

8 Історія інформаційно-психологічного протиборства : підручник / Я.М. Жарков, Л.Ф. Компанцева, В.В. Остроухов, В.М. Петрик, М.М. Присяжнюк, Є.Д. Скулиш; за заг. ред. д.ю.н., проф., засл. юриста України Є.Д. Скулиша. Київ: Наук.-вид. відділ НА СБ України, 2012. 209 с. С. 64.

9 Чухліб Т.В. Отец психологических войн. День. 2004. URL: https://day.kyiv.ua/ru/article/ukraina-incognita/otec-psihologic heskih-voyn

103 історії розвідки і контррозвідки в Україні за часів Київської Русі і Козацької Доби : наук.-практ. посіб. / А.І. Ярмоленко, В.К. Тополенко. Київ: Інститут підготовки кадрів Служби безпеки України, 1993. 25 с. С. 21.

${ }^{11}$ Історія розвідки та контррозвідки в Україні : курс лекцій : у ІІ ч. / Д.В. Вєдєнєєв, В.Г. Пилипчук, В.С. Сідак, В.К. Тополенко. Київ: Наук.-вид. відділ НА СБ України, 2010. Ч. І. 214 с. С. 27-39.

12 Макаров B.Е. Политические и социальные аспекты информационной безопасности: монография. URL: https://books. google.com.ua/books?id

13 Informacijna vijna. Vikipedija. Retrieved from. URL: https://uk.wikipedia.org/wiki/ [in Ukrainian]

14 Макаров B.Е. Политические и социальные аспекты информационной безопасности: монография. URL: https://books. google.com.ua/books?id

15 Інформаційна безпека (соціально-правові аспекти): підручник / В.В. Остроухов, В.М. Петрик, М.М. Присяжнюк та ін. Київ: КНТ, 2010. 771 с. С. 237.

16 Інформаційна безпека держави: підручник / В.М. Петрик, М.М. Присяжнюк, Д.С. Мельник та ін. Київ: ДНУ «Книжкова палата України», 2016. 264 с. С. 169.

\section{References:}

Bibliya (2002). Moskva [in Russian].

Maksymenko, M. Gh. (2015). Boghdan Khmeljnycjkyj: vid derzhavnoji ideji do Ukrajinsjkoji kozacjkoji derzhavy : metodychni rekomendaciji do 420-ji richnyci vid dnja narodzhennja Boghdana Khmeljnycjkogho. Poltava, Retrieved from: http://libgonchar.org/ images/stories/DocS/2015/Hmelnuzkuy.pdf [in Ukrainian].

Informacijna vijna. Vikipedija. URL: https://uk.wikipedia.org/wiki/ [in Ukrainian].

Grinyaev, S. (2001). Vzglyady voennykh ekspertov SShA na vedenie informatsionnogo protivoborstva. Zarubezhnoe voennoe obozrenie. Retrieved from: http://psyfactor.org/infowar1.htm [in Russian].

Jarmolenko, A.I. \& Topolenko, V.K. (1993). Z istoriji rozvidky i kontrrozvidky v Ukrajini za chasiv Kyjivsjkoji Rusi i Kozacjkoji Doby : naukovo-praktychnyj posibnyk Kyjiv: Instytut pidghotovky kadriv Sluzhby bezpeky Ukrajiny [in Ukrainian].

Vjedjenjejev, D.V. \& Pylypchuk, V.Gh. et al. (2010). Istorija rozvidky ta kontrrozvidky v Ukrajini : kurs lekcij u II ch. (Vol. 1). Kyjiv: Nauk.-vyd. viddil NA SB Ukrajiny [in Ukrainian].

Skulysh, Je.D., Zharkov, Ja.M. \& Kompanceva, L.F. (2012). Istorija informacijno-psykhologhichnogho protyborstva Kyjiv: Nauk.-vyd. viddil NA SB Ukrajiny [in Ukrainian].

Petryk, V.M., Ostroukhov, V.V. (2008). Ynformacyonno-psykhologhycheskaja bezopasnostj v epokhu ghlobalyzacyy: Uchebnoe posobye. Kyjiv [in Ukrainian]. nian].

Ostroukhov, V.V. \& Petryk, V.M. (2010). Informacijna bezpeka (socialjno-pravovi aspekty): Pidruchnyk. Kyjiv: KNT [in Ukrai-

Petryk, V.M. \& Prysjazhnjuk, M.M. (2016). Informacijna bezpeka derzhavy: Pidruchnyk. Kyjiv: DNU "Knyzhkova palata Ukrajiny" [in Ukrainian].

Makiaveli N. (1990). Gosudar'Moskva: Planeta [in Russian].

Makarov, V.E. (2015). Politicheskie $i$ sotsial'nye aspekty informatsionnoy bezopasnosti. URL: https://books.google.com.ua/ books?id [in Russian].

Petryk, V.M. \& Ostroukhov, V.V. (2006). Suchasni tekhnologhiji ta zasoby manipuljuvannja svidomistju, vedennja informacijnykh vijn i specialjnykh informacijnykh operacij: Navchaljnyj posibnyk. Kyjiv: (Rosava) [in Ukrainian].

Chukhlib, T.V. (2004). Otets psikhologicheskikh voyn. Den'. URL: https://day.kyiv.ua/ru/article/ukraina-incognita/otec-psiholo gicheskih-voyn [in Russian].

\section{Резюме}

Селіна М.Б. Спеціальна інформаційна операція: історія становлення.

У статті висвітлено зародження та розвиток спеціальної інформаційної операції, досліджено та проаналізовано взаємозв’язок між науково-технічним прогресом та її трансформацією, наведено історичні приклади використання дезінформації та пропаганди під час військово-політичних протистоянь у різні періоди історії людства.

Ключові слова: спеціальна інформаційна операція, інформаційно-психологічний вплив, дезінформація, пропаганда, гібридна війна. 
Резюме

Селина М.Б. Специальная информационная операция: история становления.

В статье раскрыто зарождение и развитие специальной информационной операции, исследована взаимосвязь между научно-техническим прогрессом и ее трансформацией, приведены исторические примеры использования дезинформации и пропаганды во время военно-политических противостояний в разные периоды истории человечества.

Ключевые слова: специальная информационная операция, информационно-психологическое влияние, дезинформация, пропаганда, гибридная война.

\section{Summary}

Maria Selina. The special information operation: history of formation.

In the article described research about appearance and the development of a special information operation which has become an integral part of the current military-political confrontation. The author defined, that skilled and timely conducted information operations gives an opportunity to gain significant advantages over the enemy, in particular, through the implementation of moral and psychological impact on the population including the armed forces of the enemy and as well as on leaderships of countries. To confirm it, in the article presented examples of the results of conducted special information operations and its individual elements in different periods of human history.

The article presents, that special information operations is not invention of the present, they appeared in ancient times simultaneously with emergence of armed confrontation, as an integral part of the armed struggle in the form of psychological way for weakening the enemy's combat spirit and raising the fighting spirit of it's own forces. The author highlights the information about the first facts of use informational and psychological influence such as: misinformation, propaganda, intimidation, which are elements of a special information operation. Their further transformation relates to the development of science and technology and the improvement of information technologies. Aa a result there are four form stages of the development of informational and psychological influence: verbal, telecommunication, technical and paper.

The article states that the appearance of the internet and the information influence on a wide audience around the world that makes special information operation one of the most effective means of achieving external and internal political goals both in military and in peacetime as evidenced by the experience of their realization. At the present stage, special information operations have become a part of a new type of war, the so-called "Hybrid war" and provides significant impact on the military and political confrontation between the opponents countries.

Key words: special information operation, information and psychological impact, misinformation, propaganda, hybrid war.

DOI: $10.36695 / 2219-5521.4 .2019 .23$

УДК 342.9

\section{В.Д. ЩЕРБАНЬ}

В'ячеслав Дмитрович Щербань, кандидат юридичних наук, доцент Навчально-наукового інституту права ім. князя Володимира Великого МАУП* ORCID: 0000-0002-6751-786X

\section{СИСТЕМА ГАРАНТІЙ ФУНКЦІОНУВАННЯ ОSINT У СФЕРІ АНТИКОРУПЦІЙНОÏ ДІЯЛЬНОСТІ В ПРАВООХОРОННИХ ОРГАНАХ}

Постановка проблеми. Призначенням гарантій функціонування OSINT у сфері антикорупційної діяльності в правоохоронних органах у юридичному аспекті є нормативне забезпечення прав і обов'язків суб'єктів, які здійснюють розвідку з відкритих джерел, а також суб'єктів, щодо яких здійснюється розвідка 3 відкритих джерел. Гарантії функціонування OSINT у сфері антикорупційної діяльності в правоохоронних органах $€$ засобом підвищення ефективності розвідки з відкритих джерел та показником того, що даний інструмент можливо застосовувати в антикорупційній діяльності правоохоронних органів. Дослідження гарантій функціонування OSINT у сфері антикорупційної діяльності в правоохоронних органах $є$ актуальним із огляду на необхідність створення належних нормативних передумов для реалізації суб'єктами розвідки з відкритих джерел своїх прав, свобод та обов'язків у цій сфері, адже лише наявність таких умов свідчить про те, що держава готова юридично забезпечити реалізацію даного інструменту. Тож сутність гарантій функціонування OSINT у сфері антикорупційної діяльності в правоохоронних органах полягає в юридичному забезпеченні функціонування цього інституту.

Аналіз останніх досліджень та публікацій. Питання розвідки на основі відкритих джерел, а також гарантій антикорупційної діяльності й гарантій функціонування правоохоронних органів досліджували такі вітчизняні науковці, як: С.В. Албул, В.В. Білоус, В.В. Бірюков, А.О. Васильєв, В.М. Галунько, Я.М. Жарков,

(C) В.Д. Щербань, 2019

* Viacheslav Shcherban, Ph.D. in Law, Associate Professor of Vladimir the Great Educational and Scientific Institute of Law of Interregional Academy of Personnel Management 